\title{
Temperature dependence of microbial degradation of organic matter in marine sediments: polysaccharide hydrolysis, oxygen consumption, and sulfate reduction
}

\author{
C. Arnosti ${ }^{1, *}$, B. B. Jørgensen ${ }^{2}$, J. Sagemann ${ }^{2}$, B. Thamdrup ${ }^{2}$ \\ 'Marine Sciences, University of North Carolina, Chapel Hill, North Carolina 27599-3300, USA \\ ${ }^{2}$ Max Planck Institute for Marine Microbiology, Celsiusstrasse 1, D-28359 Bremen, Germany
}

\begin{abstract}
The temperature dependence of representative initial and terminal steps of organic carbon remineralization was measured at 2 temperate sites with annual temperature ranges of 0 to $30^{\circ} \mathrm{C}$ and 4 to $15^{\circ} \mathrm{C}$ and 2 Arctic sites with temperatures of 2.6 and $-1.7^{\circ} \mathrm{C}$. Slurried sediments were incubated in a temperature gradient block spanning a temperature range of ca $45^{\circ} \mathrm{C}$. The initial step of organic carbon remineralization, macromolecule hydrolysis, was measured via the enzymatic hydrolysis of fluorescently labeled polysaccharides. The terminal steps of organic carbon remineralization were monitored through consumption of oxygen and reduction of ${ }^{35} \mathrm{SO}_{4}{ }^{2-}$ At each of the 4 sites, the temperature response of the initial step of organic carbon remineralization was similar to that of the terminal steps. Although optimum temperatures were always well above ambient environmental temperatures, optimum temperatures generally decreased with decreasing environmental temperatures. Activity at $5^{\circ} \mathrm{C}$ as a percentage of highest activity was highest in the Arctic sites and lowest in the warmest temperate site. The highest potential rates of substrate hydrolysis were measured in the Arctic, while the highest rates of oxygen consumption and sulfate reduction were measured at the warmest temperate site. Potential rates of extracellular enzymatic hydrolysis (at least for this class of pullulanase enzymes) do not appear to limit organic carbon turnover in the Arctic. These results suggest that organic carbon turnover in the cold Arctic is not intrinsically slower than carbon turnover in temperate environments; sedimentary metabolism in Arctic sediments may be controlled more by organic matter supply than by temperature.
\end{abstract}

KEY WORDS: Temperature C Carbon remineralization - Extracellular enzymes

\section{INTRODUCTION}

The observation that enzyme activities and organic carbon remineralization rates are often lower during cold seasons in temperate environments (e.g. Godshalk \& Wetzel 1978, Crill \& Martens 1987, Mayer 1989) raises questions about the effects of permanently cold temperatures on remineralization rates in the deep and polar oceans. Pomeroy et al. (1991) found a relatively low microbial response to spring phyto-

\footnotetext{
·E-mail: arnosti@marine.unc.edu
}

plankton blooms in Conception Bay, Newfoundland, Canada, and hypothesized that bacterial growth was limited at low temperatures by restrictions on cellularlevel processes, such as permeability of membranes or temperature limitation of enzyme activities. Reichardt (1987) found that the activities of enzymes extracted from Antarctic sediments showed temperature optima of 40 to $55^{\circ} \mathrm{C}$. He concluded that the enzymes were not well adapted to cold temperatures and suggested that decomposition of organic matter in cold benthic environments is restricted in its initial step, unless increased enzyme production or accumulation can compensate for lack of temperature adaptation. As dis- 
cussed by Thingstad \& Martinussen (1991), food webs are a balance of dynamic processes; if these processes differ in their temperature sensitivity in polar and temperate regions, the balance between various aspects of organic matter production and degradation may also differ.

In marine sediments, a complex community of bacteria is responsible for organic matter remineralization. In order to obtain carbon and energy from sedimentary organic matter, bacteria must degrade organic macromolecules such as proteins, nucleic acids, and polysaccharides to simpler substrates and $\mathrm{CO}_{2}$. Because bacterial membranes generally cannot be permeated by substrates with a molecular weight greater than approximately $600 \mathrm{Da}$ (Weiss et al. 1991), extracellular hydrolysis of macromolecules to smaller substrates which can be transported into a bacterial cell is the initial step in degradation of organic matter. Further degradation of organic substrates usually requires the concerted action of a range of bacteria (a microbial food chain). Oxidation of organic carbon to $\mathrm{CO}_{2}$, with concurrent utilization of electron acceptors such as oxygen or sulfate, is the terminal step of organic carbon remineralization. Since remineralization of organic carbon is a multi-step process, different temperature responses of specific groups of bacteria or specific enzymatic processes will be reflected in the overall organic carbon remineralization rate.

Terminal processes of organic carbon remineralization such as sulfate reduction and oxygen consumption have been measured in environments which experience vastly different temperature regimes, ranging from the polar oceans to hydrothermal sediments (e.g. Jørgensen 1982, Nedwell et al. 1993, Elsgaard et al. 1994); the specific temperature dependence of sulfate reduction has also been investigated (Westrich \& Berner 1988, Isaksen et al. 1994, Isaksen \& Jørgensen 1996, and references therein). Elsgaard et al. (1994) found that addition of substrates to hydrothermal sediments from the Guayamas Basin not only stimulated sulfate reduction, it also lowered the optimal temperature of thermophilic sulfate reduction by 5 to $10^{\circ} \mathrm{C}$, indicating that the temperature response of fermentative bacteria was dominating the net community response and that these fermentative bacteria had a higher temperature optimum than the sulfate-reducing bacteria

Several studies of extracellular enzymes isolated from marine bacteria support the possibility that the temperature optimum of the initial step of organic carbon remineralization may exceed the temperature optima of terminal steps of remineralization. Extracellular enzymes are frequently found to function at high rates at temperatures above the growth ranges of the organisms which produced the enzymes. The extracel- lular pullulanases produced by the hyperthermophiles Thermococcus litoralis and Pyrococcus furiosus, for example, are still active at temperatures of 130 to $140^{\circ} \mathrm{C}$, far above the life temperatures of the organisms (Brown \& Kelly 1993). Similarly, a study of psychrophilic bacteria isolated from the polar oceans showed that maximum growth temperatures for the bacteria did not exceed $20^{\circ} \mathrm{C}$, while amylase and protease enzymes isolated from these bacteria functioned at optimum rates in the temperature range of 30 to $50^{\circ} \mathrm{C}$, with maximum temperatures in the range of 40 to $60^{\circ} \mathrm{C}$ (Helmke \& Weyland 1991).

The extent to which studies of isolated enzymes are representative of community responses is unclear, however, since production of extracellular enzymes may be subject to temperature control which is distinct from the temperature optima of specific enzymes. For the Antarctic bacterium Alteromonas haloplanctis, for example, the excretion of $\alpha$-amylase, a polysaccharide-hydrolyzing enzyme, is severely restricted at growth temperatures higher than the organism's normal growth range (Feller et al. 1992). Burini (1994) found that the production of enzymes from a 'psychrotrophic' bacterium was maximal at temperatures more than $10^{\circ} \mathrm{C}$ lower than the optimal growth temperature of the bacterium. The temperature response of substrate hydrolysis in marine sediments therefore may be dictated by the temperature dependence of enzyme production as well as by the kinetic characteristics of the enzymes themselves.

In order to determine the effects of environmental temperature on organic carbon remineralization, the responses for both the initial and the terminal steps of organic carbon remineralization should be investigated. Do the initial and terminal steps of carbon remineralization differ in temperature sensitivity? We focus here on the temperature responses of extracellular enzymatic hydrolysis of macromolecules as the initial step, and oxygen consumption and sulfate reduction as the terminal steps, of organic carbon remineralization. Do relative temperature responses differ between the microbial communities of temperate and permanently cold environments? We compare the temperature responses of the microbial communities at 2 temperate sites to the temperature responses at 2 permanently cold Arctic sites in order to determine whether communities in permanently cold environments function more effectively at lower temperatures than do communities which experience cold temperatures only on a seasonal basis.

To determine the temperature responses of the initial and terminal steps of organic carbon remineralization, sediments from 4 sites were incubated in a temperature gradient block spanning a range of temperatures. Extracellular enzymatic hydrolysis of polysaccharides 
was measured using a new technique (Arnosti 1995. 1996); polysaccharides were chosen as the target macromolecule for measurement of hydrolysis rate because they are a major component of marine organic matter (20 to $40 \%$ of phytoplankton biomass; Parsons et al. 1961). Pullulan $[\alpha(1,6)$-linked maltotriose units; molecular weight $200000 \mathrm{Da}$ ] was chosen as the specific polysaccharide substrate for this study because pullulanase activity has been demonstrated in a range of marine bacteria (Brown et al. 1990, Antranikian 1992, Arnosti \& Repeta 1994), and in sediments from a number of sites (Arnosti et al. 1994, Arnosti 1995 , unpubl. data). Sulfate reduction rate and oxygen consumption rates were measured as described below. The combined picture obtained from these measurements of initial and terminal steps in organic carbon turnover yields further insights into the processes controlling organic carbon remineralization in temperate and permanently cold marine sediments.

\section{METHODS}

Study sites. Sediment from 4 sites was collected for this study: 2 temperate sites which experience considerably different seasonal variations in temperature, and 2 Arctic sites which experience permanently low, but slightly different, temperatures.

Weddewarden: Samples were collected by hand from the tidal flat of Weddewarden, on the east side of the Weser estuary in northern Germany. This outer portion of the estuary is part of the southern margin of the North Sea. The sediments are silty, with $2 \%$ organic carbon (dry weight). Salinity varies seasonally between 4 and $20 \%$, while the annual temperature range is from 0 to ca $30^{\circ} \mathrm{C}$ (Sagemann et al. 1996). Sediment was collected for sulfate reduction and hydrolysis rate measurements in June 1995, when the sediment surface temperature was $20^{\circ} \mathrm{C}$. Sediment for oxygen consumption measurements was sampled in August 1996 (daytime surface temperature: $26^{\circ} \mathrm{C}$ ). Sediments for sulfate reduction and oxygen consumption measurements were used immediately, while the sediments for hydrolysis measurements were stored for $4 \mathrm{~d}$ at $9^{\circ} \mathrm{C}$ prior to use.

Aarhus Bay: Samples were collected with a box core at Station 6, Aarhus Bay, Denmark (Thamdrup et al. 1994). The water depth is $15 \mathrm{~m}$, and the sediment is silty clay (organic carbon: $-3 \%$ dry weight). In situ temperatures vary between 4 and $15^{\circ} \mathrm{C}$ annually (Rasmussen \& Jørgensen 1992). Aarhus Bay is located in the North Sea-Baltic Sea transition, and salinity of bottom waters varies between 23 and $33 \%$. Sediments for sulfate reduction rate measurements were collected in April 1990 (sediment temperature: $7^{\circ} \mathrm{C}$ ). The samples for hydrolysis rate measurements were collected in July 1995 (sediment temperature: $8^{\circ} \mathrm{C}$ ). and stored for $3 \mathrm{~d}$ at $9^{\circ} \mathrm{C}$ prior to use.

Svalbard-Hornsund and Storfjorden: Sediments were collected with a multicorer at 2 sites near Svalbard in the Arctic Ocean during September/October 1995. Hornsund is located at $76^{\circ} 58^{\prime} 20^{\prime \prime} \mathrm{N}, 15^{\circ} 34^{\prime}$ $50^{\prime \prime} \mathrm{W}$. Water depth is $155 \mathrm{~m}$, and the bottom water temperature was $2.6^{\circ} \mathrm{C}$. Storfjorden is located at $77^{\circ} 33^{\prime} 00^{\prime \prime} \mathrm{N}, 1^{\circ} 05^{\prime} 00^{\prime \prime} \mathrm{W}$, with a water depth of $175 \mathrm{~m}$ and a bottom water temperature of $-1.7^{\circ} \mathrm{C}$. Sediments at Hornsund are soft and light-brown colored in the upper $5 \mathrm{~cm}$ and contain numerous worm burrows. Below ca $5 \mathrm{~cm}$ depth, the sediments are a clayey, darker mottled gray and brown color. Sedimentary organic carbon content at Hornsund was $2 \%$ at the surface and decreased to $1.7 \%$ at $10 \mathrm{~cm}$. At Storfjorden, the fine-grained watery surface sediment layer is light brown, grading to dark brown over the upper 2 $\mathrm{cm}$. Below the upper $2 \mathrm{~cm}$, the sediments are gray and clayey. Organic carbon content was approximately $2.4 \%$ throughout the cores.

Temperature gradient block (TGB). The TGB consisted of a $2 \mathrm{~m} \times 15 \mathrm{~cm} \times 15 \mathrm{~cm}$ thermally insulated aluminum block heated electrically at one end and cooled at the other with a refrigerated circulation thermostat. The block contained 30 rows of 4 parallel holes for sample vials, each row separated by a hole for temperature measurement. The Weddewarden and Aarhus Bay hydrolysis rate measurements and all of the sulfate reduction rate measurements were made in a stationary TGB, while all of the oxygen consumption rate measurements and the Hornsund and Storfjorden substrate hydrolysis rate measurements were made in a rotating $\mathrm{TGB}$. During incubation with the rotating $\mathrm{TGB}$, the entire TGB rotated at approximately $30 \mathrm{rpm}$ around its longitudinal axis, $\pm 60^{\circ}$ relative to vertical.

Polysaccharide hydrolysis measurements. Substrate synthesis: Fluorescently labeled pullulan (FLA-pullulan) was prepared and characterized using the method described in Arnosti (1996).

Core collection and sediment preparation: Weddewarden: Surface (upper $3 \mathrm{~cm}$ ) sediments were homogenized, and a 1:1(v/v) sediment:water slurry was prepared with water collected at the same site. Nine ml of slurry was dispensed into replicate glass tubes, and FLA-pullulan (total addition: 2.9 nmol; final concentration: $0.32 \mu \mathrm{M}$ ) was added to each tube. The tubes were sealed, incubated, and sampled at 9, 17, and $30 \mathrm{~h}$, using the procedure described below.

Aarhus Bay: Sediments were collected from the sulfate-reducing zone at Station 6 and stored in a chilled container for transport back to the lab. A $1.5: 1(\mathrm{v} / \mathrm{v})$ slurry was prepared with bottom water which had been sparged with $N_{2}$. Under a stream of $N_{2}, 10 \mathrm{ml}$ of 
slurry was dispensed into glass tubes, and $2.8 \mathrm{nmol}$ FLA-pullulan was added to each tube (final concentration: $0.28 \mu \mathrm{M}$ ). The tubes were sealed, incubated, and sampled at 12, 23 (only a few samples), 36, and 73 h, as described below.

Hornsund and Storfjorden: Sediments were collected with a multicorer, and the overlying water was siphoned off without disturbing the upper sediment layers. The upper $0.5 \mathrm{~cm}$ layer was carefully removed from 6 cores and homogenized. A $1: 1(\mathrm{v} / \mathrm{v})$ slurry of the bottom water and surface sediments was prepared and incubated at in situ temperature for ca $1 \mathrm{~h}$ while experimental preparations were completed. For Hornsund samples, $9 \mathrm{ml}$ of slurry was dispensed into replicate glass tubes, and 2.4 nmol FLA-pullulan was added to each tube (final concentration: $0.27 \mu \mathrm{M}$ ). For Storfjorden samples, $10 \mathrm{ml}$ of slurry was dispensed into the glass tubes, and $6.0 \mathrm{nmol}$ FLA-pullulan was added to each tube (final concentration: $0.60 \mu \mathrm{M}$ ). The tubes were sealed and incubated in the rotating TGB. At Hornsund, hydrolysis was monitored in a few samples at 9 and $14 \mathrm{~h}_{i}$ the entire block was sampled at 18 and $48 \mathrm{~h}$. At Storfjorden, a few samples were monitored at $9,16,18,36$, and $48 \mathrm{~h}$; the entire gradient block was sampled at 30 and $60 \mathrm{~h}$.

Sample analysis: One to two $\mathrm{ml}$ of sediment slurry was filtered through $0.2 \mu \mathrm{m}$ pore-size filters to remove particles. A few samples were analyzed immediately, and the remainder were stored frozen until analysis, either aboard ship or ashore. Re-analysis of samples run 'fresh' and after freezing and thawing demonstrated that frozen storage had no effect on hydrolysis profiles. Samples were analyzed using a low-pressure gel permeation chromatography system attached to a fluorescence detector (Waters Model 470 for Weddewarden and Aarhus Bay samples, and for shipboard analyses of Hornsund and Storfjorden samples; Hitachi model L-7480 for Hornsund and Storfjorden samples analyzed ashore), as described in Arnosti (in press). The fluorescence signal was integrated with an $\mathrm{HP}$ Model 3395 integrator. The gel permeation chromatography system separates polysaccharide hydrolysis products by molecular weight; the analysis of a few samples from a given time point showed the progression of substrate hydrolysis with time and temperature and provided a guide for selecting subsequent sampling times.

Rate calculations: Potential hydrolysis rates were calculated using a conservative model (the 'sieve model') intended to provide a lower boundary value for the potential hydrolysis rate (Arnosti 1996). All rates were calculated on the basis of $\mathrm{cm}^{3}$ of sediment.

Blanks, reproducibility: Blanks included sediments incubated without addition of substrate, to check the background level. of porewater fluorescence at excita- tion and emission wavelengths of 490 and $530 \mathrm{~nm}$. To determine whether any substrate was thermally (not biologically) hydrolyzed, $200 \mu \mathrm{l}$ of FLA-pullulan was added to $0.2 \mu \mathrm{m}$-filtered $\mathrm{Q}$-water and these samples were incubated at 4 temperatures along the TGB, including both the highest and lowest incubation temperatures. At the completion of the experiments, sediment slurries incubated without addition of substrate did not yield any measurable fluorescence at excitation and emission wavelengths of 490 and $530 \mathrm{~nm}$. None of the substrate blanks showed measurable loss of fluorescent tag throughout the time course of the incubations. Duplicate temperature slots were occupied at 5 different temperatures for both Hornsund and Storfjorden; all data points, including duplicate determinations, are plotted in Figs. $3 \& 4$.

Oxygen consumption measurements. Sediment collection and preparation: For the Svalbard stations, the upper oxic layer ( 0 to $0.5 \mathrm{~cm}$ or 0 to $0.75 \mathrm{~cm}$ ) was sampled from 5 to 6 cores, while for Weddewarden, the upper 2 to $3 \mathrm{~mm}$ were sampled directly at low tide. The sediments were immediately passed through a $125 \mu \mathrm{m}$ sieve to remove fauna and shell debris and to break up any aggregates in which anoxia could develop. Sieving removed less than $5 \%$ of the dry sediment matter. At Svalbard, sediment handling on deck (air temperature of 0 to $2^{\circ} \mathrm{C}$ ) lasted less than $1 \mathrm{~h}$. At in situ temperature, the sieved sediment was diluted 10- (Storfjorden) or 17 -fold (Hornsund) with bottom water. The Weddewarden sediments were handled at $20^{\circ} \mathrm{C}$ and diluted 30-fold. To exclude any influence of bottom water bacteria, the bottom water was filtered $10.2 \mu \mathrm{m}$ pore-size Nucleopore filter) just before use. The sediment was diluted to reduce reaction speed for ease of measurement. A control incubation of Storfjorden sediment at $1: 1(\mathrm{v} / \mathrm{v})$ dilution (similar to the hydrolysis and sulfate reduction incubations) showed that neither absolute rates nor their temperature dependence were significantly affected by the greater dilution (Thamdrup unpubl. dataj. The sediment was kept in suspension by magnetic stirring and bubbled with air for 4 , 12, and $40 \mathrm{~h}$ at Storfjorden, Hornsund, and Weddewarden, respectively. This step served to oxidize reduced inorganic species such as $\mathrm{Mn}^{2+}$ and $\mathrm{Fe}^{2+}$ and, thus, minimize abiotic or lithotrophic oxygen consumption. Principles of the method are described further elsewhere (Thamdrup et al. in press).

Sample analysis: The slurries were distributed into glass test tubes placed open in a TGB which spanned the temperature range of -2 to $45^{\circ} \mathrm{C}$ at ca $1.5^{\circ} \mathrm{C}$ intervals. The test tubes in the TGB were shaken several times during a 1 h atmospheric equilibration period, thus avoiding air supersaturation at the higher temperatures. The tubes were then sealed with butyl rubber stoppers without headspace, and a set of samples 
from all temperatures was taken at the beginning of the incubation to measure the initial oxygen concentration. Rotation of the TGB began immediately afterwards in order to maintain the sediment in suspension. Different incubation times were tested to obtain the optimal signal without oxygen depletion and to check for linearity of rates. Incubation times for the results described here were 6,5 , and 2 h at Hornsund, Storfjorden, and Weddewarden, respectively. At the conclusion of the incubation, test tubes were transferred to ice water, immediately centrifuged at $0^{\circ} \mathrm{C}$, and kept in ice water during sampling. After centrifugation, oxygen consumption in the supernatant was negligible due to diffusive limitations in the sediment pellet. Subsamples of the supernatant for $\mathrm{O}_{2}$ determination were withdrawn from just above the sediment pellet using $5 \mathrm{ml}$ all-glass syringes equipped with a stopcock and a $1 \mathrm{~mm}$ inner diameter steel canula. Oxygen was determined by the Winkler method (Grasshoff 1983) by injecting the reagents in the glass syringes and titrating the entire volume. Blanks were $<5 \mu \mathrm{M}$ and the estimated relative standard deviation, RSD, $2 \%$. The data presented here are from one of the duplicate experiments from each station; these duplicates yielded closely comparable results, as exemplified by $Q_{10}$ values calculated for replicate experiments at Hornsund $\left(Q_{10}=1.84 \pm 0.15\right)$ and Storfjorden $\left(Q_{10}=1.77 \pm 0.12\right.$; Thamdrup \& Fleischer in press) The single exception was one point for oxygen consumption $\left(7.9 \mu \mathrm{mol} \mathrm{cm}^{-3} \mathrm{~d}^{-1}\right.$ at $44^{\circ} \mathrm{C}$ ) at Storfjorden; this single, widely deviating point was not observed in any other experiments at Storfjorden or Hornsund, and we have excluded this point from Fig. 4. Further results will be discussed in detail elsewhere (Thamdrup \& Fleischer in press).

Sulfate reduction measurements. Sediment collection/preparation: Sediment slices ( $5 \mathrm{~cm}$ thick) from the anoxic zone from 5 or 6 multicores (hand-driven perspex tubes at Weddewarden and Aarhus Bay) were pooled. Data presented here are from sediment depths of 10 to $15 \mathrm{~cm}$ for Weddewarden, 5 to $10 \mathrm{~cm}$ for Aarhus Bay, 8 to $13 \mathrm{~cm}$ for Hornsund, and 9 to $14 \mathrm{~cm}$ for Storfjorden, which is at or just below the depth of maximum sulfate reduction rates. Slurries were prepared by $2: 1$ to $1: 1$ (sediment:water) dilution with oxygenfree bottom water. Due to high content of shell debris and some sand, the Aarhus Bay slurry was sieved (1 mm) and decanted once the coarse sand had settled. The slurries were homogenized by magnetic stirring and 8 to $10 \mathrm{ml}$ decanted into glass tubes. After sealing with rubber stoppers, the tubes were incubated in the TGB for $1 \mathrm{~h}$ before addition of $100 \mu$ tracer solution ( 1 to $16 \mu \mathrm{Ci}^{35} \mathrm{SO}_{4}{ }^{2-}$ ). All preparations were carried out under $\mathrm{N}_{2}$. Sulfate reduction rates in the slurries at in situ temperatures were similar to rates determined at the corresponding depth in intact sediment cores from the Svalbard sites (Sagemann et al. in press).

Sample analysis: After $4 \mathrm{~h}$ incubation time, $1 \mathrm{ml}$ of $20 \%(\mathrm{w} / \mathrm{v}) \mathrm{Zn}$-acetate solution was added to each tube to terminate activity. The tubes were either frozen or stored at $4{ }^{\circ} \mathrm{C}$. Reduced ${ }^{35} \mathrm{~S}$ was analyzed by the singlestep chromium reduction method (Fossing \& Jørgensen 1989), and sulfate reduction rates were calculated per $\mathrm{cm}^{3}$ of sediment as described by Jørgensen (1978). The detection limit was between 0.5 and $1.0 \mathrm{nmol} \mathrm{cm}^{-3}$ $\mathrm{d}^{-1}$, depending on added activity and incubation time. For Weddewarden and Storfjorden, 4 replicate measurements were made at each temperature (avg. SD: 18 and $13 \%$, respectively), 2 to 3 replicates were made at each temperature for Hornsund (avg. SD: 15\%), and single determinations were made at each temperature for Aarhus Bay.

\section{RESULTS}

Similarities between incubation temperature and activity are observed for all sites and processes (Figs. 1 to 4). At Weddewarden, polysaccharide hydrolysis, oxygen consumption, and sulfate reduction are all characterized by continual increases with increasing temperature up to an optimum - for all processesnear 35 to $40^{\circ} \mathrm{C}$ (Fig. 1). The profiles for oxygen consumption (highest rate at $41^{\circ} \mathrm{C}$ ) and hydrolysis (highest measured rate at $37^{\circ} \mathrm{C}$, which was also the highest temperature at which measurements were made) match quite closely. The sulfate reduction rate reaches an optimum at $34^{\circ} \mathrm{C}$. Oxygen consumption and sulfate reduction decrease rapidly at temperatures in excess of $41^{\circ} \mathrm{C}$ and $34^{\circ} \mathrm{C}$, respectively.

Temperature optima for Aarhus Bay (Fig. 2), a cooler environment with a more moderate seasonal temperature range than Weddewarden, are somewhat lower than for Weddewarden. Hydrolysis rates rise sharply with increasing temperature between -2.5 and $21^{\circ} \mathrm{C}$, remain relatively constant between 21 and $32^{\circ} \mathrm{C}$, and drop above $32^{\circ} \mathrm{C}$. The sulfate reduction rate increases from -2 to $32^{\circ} \mathrm{C}$ (optimum temperature) and drops rapidly above $32^{\circ} \mathrm{C}$. Temperature-dependent $\mathrm{O}_{2}$ consumption profiles at Aarhus Bay reported by Hansen et al. (1994) and Thamdrup et al. (in press) are also quite similar to the hydrolysis profiles reported here.

At Hornsund (Fig. 3), the hydrolysis rate optimum $\left(15^{\circ} \mathrm{C}\right)$, the oxygen consumption optimum $\left(20^{\circ} \mathrm{C}\right)$, and the sulfate reduction rate optimum $\left(26^{\circ} \mathrm{C}\right)$ are all found at temperatures lower than at Weddewarden or Aarhus Bay. Above their respective optimum temperatures, all 3 activities decrease with higher temperature.

At Storfjorden, the coldest station, the hydrolysis profile (Fig. 4) shows a high optimum temperature 


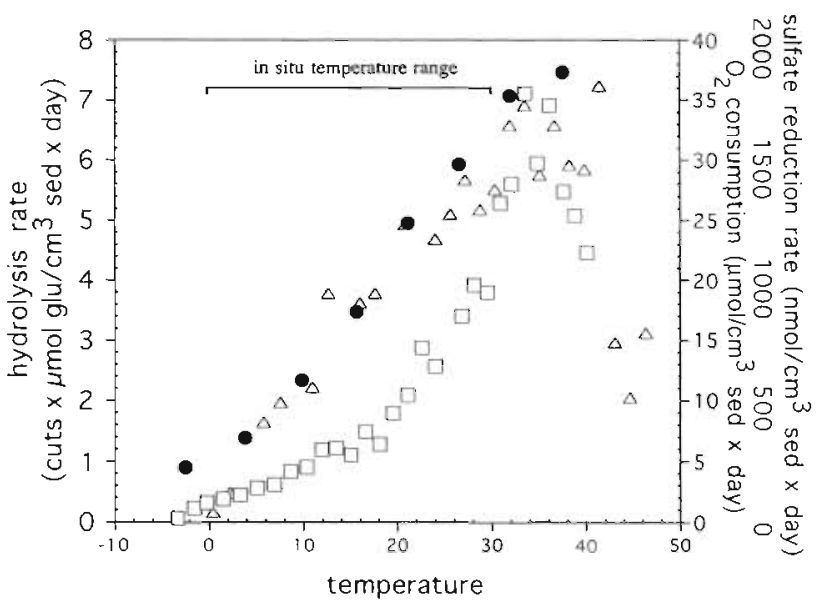

Fig. 1 Temperature dependence of polysaccharide hydrolysis $(\bullet)$, oxygen consumption $(\Delta)$, and sulfate reduction ( $\square$ ) rates in slurried intertidal sediments from Weddewarden (Germany). North Sea. In situ temperatures vary seasonally from 0 to $30^{\circ} \mathrm{C}$. (Oxygen consumption data from Thamdrup et al. in press)

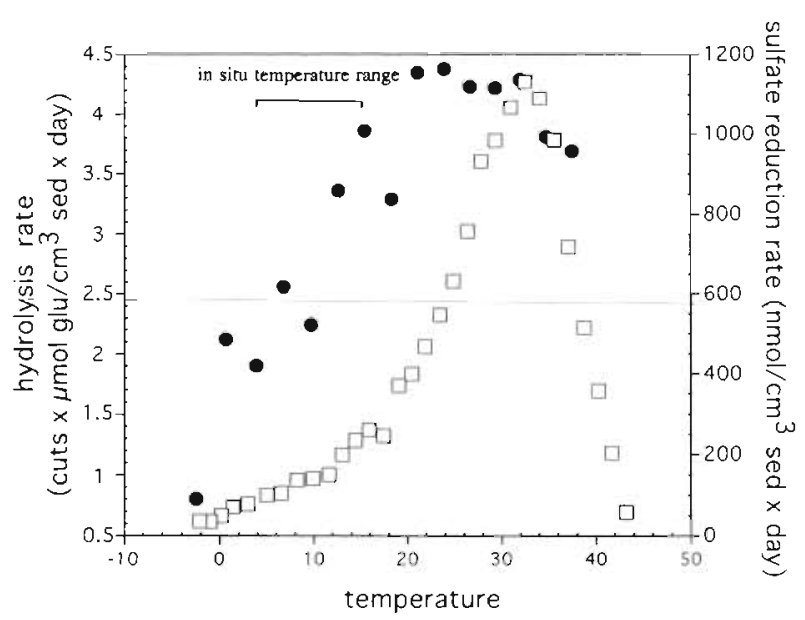

Fig. 2. Temperature dependence of polysaccharide hydrolysis $(\bullet)$, and sulfate reduction $(\square)$ rates in slurried sediments from Aarhus Bay (Denmark), Baltic Sea-North Sea transition. In situ temperatures range between 4 and $15^{\circ} \mathrm{C}$ annually

$\left(34^{\circ} \mathrm{C}\right)_{i}$ high levels of activity are observed in the range from 14 to $34^{\circ} \mathrm{C}$. The temperature optima for oxygen consumption $\left(20^{\circ} \mathrm{C}\right)$ and sulfate reduction $\left(28^{\circ} \mathrm{C}\right)$ are close to the optima measured at Hornsund (Fig. 3). Storfjorden is the only station at which the optimum. temperature for substrate hydrolysis considerably exceeds the optimum temperature of sulfate reduction; in general, the optimum temperature of sulfate reduction is close to or greater than the temperature optima of substrate hydrolysis and oxygen consumption. The hydrolysis rate and oxygen consumption profiles at Storfjorden match one another up to a temperature of ca $25^{\circ} \mathrm{C}$ and diverge above this temperature. The tem-

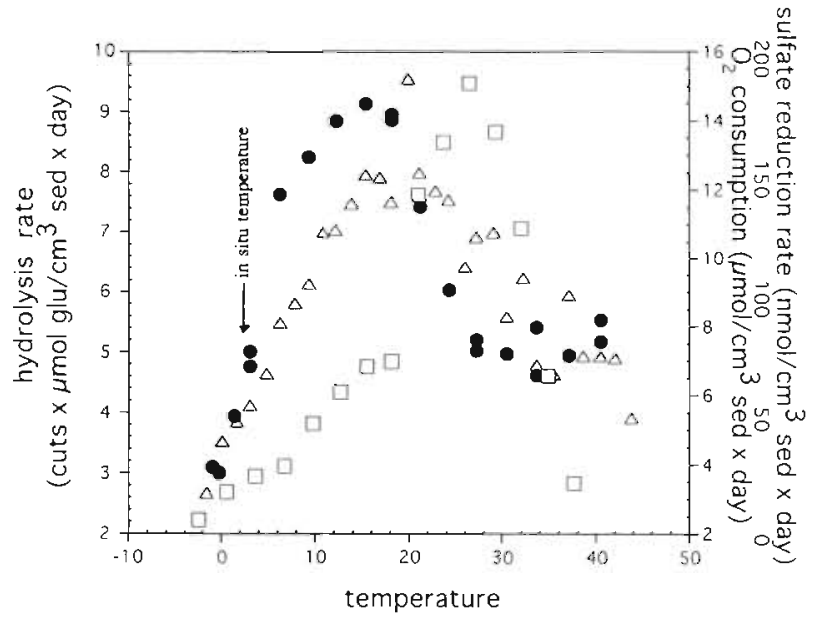

Fig. 3. Temperature dependence of polysaccharide hydrolysis $(\bullet)$, oxygen consumption $(\Delta)$, and sulfate reduction ( $\square$ ) rates in slurried sediments from Hornsund (Svalbard), Arctic Ocean. In situ temperature was $2.6^{\circ} \mathrm{C}$. (Oxygen consumption data from Thamdrup \& Fleischer in press)

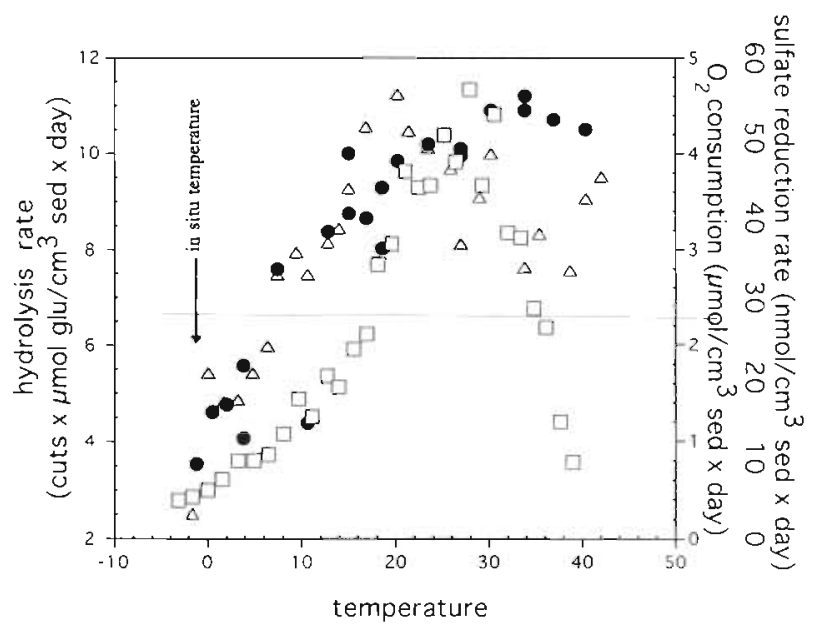

Fig. 4. Temperature dependence of polysaccharide hydrolysis $(\bullet)$, oxygen consumption $(\Delta)$, and sulfate reduction ( $\square$ ) rates in slurried sediments from Storfjorden (Svalbard), Arctic Ocean. In situ temperature was $-1.7^{\circ} \mathrm{C}$. (Sulfate reduction rate data from Sagemann et al. in press; oxygen consumption data from Thamdrup \& Fleischer in press)

perature optimum for sulfate reduction at Storfjorden is slightly higher than that observed at Hornsund (28 vs $26^{\circ} \mathrm{C}$ ), but the decrease in sulfate reduction rate with increasing temperature is similar at both stations. The maximum substrate hydrolysis rates measured at Hornsund and Storfjorden are comparable, although observed at different optimum temperatures, while rates of oxygen consumption and sulfate reduction are lower (by more than a factor of 3) at Storfjorden as compared to Hornsund.

While the optimum temperatures are considerably higher than ambient environmental temperatures, the 
Table 1. Rates and temperatures $\left({ }^{\circ} \mathrm{C}\right.$, in parentheses $)$ of highest activity for Storfjorden, Hornsund, Aarhus Bay, and Weddewarden

\begin{tabular}{|c|c|c|c|c|c|}
\hline & $\begin{array}{c}\text { In situ } \\
\text { temperature }\end{array}$ & lcuts & $\begin{array}{l}\text { Hydrolysis } \\
\cdot \text { umol glu } \cdot \mathrm{cm}^{-3} \cdot \mathrm{d}^{-1} \text { ) }\end{array}$ & $\begin{array}{l}\mathrm{O}_{2} \text { consumption } \\
\left(\mu \mathrm{mol} \mathrm{cm}^{-3} \mathrm{~d}^{-1}\right)\end{array}$ & $\begin{array}{l}\mathrm{SO}_{4}{ }^{2-} \text { reduction } \\
\left(\mathrm{nmol} \mathrm{cm}^{-3} \mathrm{~d}^{-1}\right)\end{array}$ \\
\hline Storfjorden & 1.7 & & $11.2(34)$ & $4.6(20)$ & $62(28)$ \\
\hline Hornsund & 2.6 & & $9.1(15)$ & $15(20)$ & $190(26)$ \\
\hline Aarhus Bay & $4-15$ & & $4.4(24)$ & & 565 (32) \\
\hline Weddewarden & $0-30$ & & $7.5(37)$ & $36(41)$ & $1970(34)$ \\
\hline
\end{tabular}

optima were usually higher in more temperate environments and lower in the Arctic (Table 1). The trends in rates measured at the optimum temperatures, however, differ significantly for the initial and terminal steps of organic carbon remineralization. The highest substrate hydrolysis rates measured in the colder environments are considerably higher than those measured in the temperate environments, while maximum levels of oxygen consumption and sulfate reduction decrease in colder environments. The implications of these trends are discussed further in the next section.

\section{DISCUSSION}

\section{Temperature responses of initial and terminal steps of remineralization}

While temperature optima differ somewhat, the temperature responses of the initial and terminal steps of aerobic and anaerobic organic carbon remineralization are similar (Figs. 1 to 4 ). We consider this similarity remarkable, considering the fact that different organisms, with different membrane lipids, enzymes, and transport systems, are involved in the multitude of steps needed to convert organic carbon to $\mathrm{CO}_{2}$.

In all cases, the optimum temperatures for substrate hydrolysis, sulfate reduction, and oxygen consumption are well above the range of ambient environmental temperatures. A similar phenomenon has been observed for a variety of microbial processes (e.g. Li \& Dickie 1987. Helmke \& Weyland 1991). Isaksen \& Jorgensen (1996) noted that the cardinal temperatures for growth and for metabolic activity can differ substantially; they found that a 'psychrotrophic' bacterium isolated from a Danish fjord reduced sulfate optimally at $28^{\circ} \mathrm{C}$, even though it could not grow at temperatures in excess of $24^{\circ} \mathrm{C}$. Because this study focuses on carbon remineralization processes carried out by the entire microbial community, not the physiology of isolated bacterial species, we cannot determine whether the temperature ranges of oxygen consumption, sulfate reduction, and substrate hydrolysis are within the growth ranges of the diverse organisms responsible for carrying out these processes. The data show, however, that the temperature responses of the processes responsible for the initial and terminal stages of organic carbon remineralization are similar.

Since rates of sulfate reduction, oxygen consumption, and substrate hydrolysis were relatively high across a wide temperature range, temperature profiles span conventional classification boundaries (Morita 1975). In the following discussion, we will refer to a metabolic activity as psychrophilic if it has a minimum temperature $<0^{\circ} \mathrm{C}$, an optimum temperature $\leq 15^{\circ} \mathrm{C}$, and a maximum temperature $\leq 20^{\circ} \mathrm{C}$. Metabolic activities with minimum temperatures $\leq 0^{\circ} \mathrm{C}$, optimum temperatures $\leq 25^{\circ} \mathrm{C}$, and maximum temperatures $\leq 35^{\circ} \mathrm{C}$ are referred to as psychrotolerant, and activities with optima in the range of $-25-40^{\circ} \mathrm{C}$ and maxima at $-35-45^{\circ} \mathrm{C}$ are referred to as mesophilic.

The temperature response of all of the processes measured were predominantly mesophilic or psychrotolerant (Figs. 1 to 4, Table 1). Measurable activity tended to extend to temperatures below $0^{\circ} \mathrm{C}$, however, even for responses which might be considered mesophilic (sulfate reduction at all sites, oxygen consumption and substrate hydrolysis at Weddewarden). Likewise, responses which showed predominantly psychrotolerant characteristics (oxygen consumption at Hornsund and Storfjorden, substrate hydrolysis at Aarhus Bay and Hornsund) also demonstrated substantial activity at temperatures in excess of $35^{\circ} \mathrm{C}$. Note that the optimum substrate hydrolysis temperature obtained for Weddewarden corresponds to the maximum temperature at which measurements were made: a higher optimum temperature might have been found if the incubations had extended into a higher temperature range. The temperature response of substrate hydrolysis at Storfjorden, the coldest station studied, could be considered mesophilic, with an optimum temperature of $34^{\circ} \mathrm{C}$, and substantial activity above $35^{\circ} \mathrm{C}$. Activity at temperatures from 14 to $34^{\circ} \mathrm{C}$ was generally high (Fig. 4), however, and activity below $0^{\circ} \mathrm{C}$ was still substantial and was comparable to activity measured at the same temperature at Hornsund.

The predominance of a mesophilic/psychrotolerant response is consistent with other reports which indicate that psychrophilic bacteria do not dominate in seawater or sediments of permanently cold environ- 
ments (Delille \& Perret 1989, Nedwell \& Rutter 1994, Feller et al. 1996). Norkrans \& Stehn (1978) found that approximately two-thirds of the 143 strains of bacteria isolated from deep Norwegian Sea sediments were 'psychrotrophs' (psychrotolerant). Tan \& Rüger (1991) isolated bacteria from water samples collected at 25, 200, and $1000 \mathrm{~m}$ in the Fram Strait and the Western Greenland Sea. Although the incubation temperature was $2^{\circ} \mathrm{C}$, only 'psychrotrophic' (psychrotolerant) bacteria were isolated. In Antarctic sediments, the majority $(87 \%)$ of the isolated cellulose degrading bacteria were also 'psychrotrophic' (psychrotolerant), not psychrophilic (Reichardt 1988).

\section{Correlation of temperature responses with environmental conditions}

Although optimum temperatures of substrate hydrolysis, sulfate reduction, and oxygen consumption were higher than ambient environmental temperatures, activity at low temperature $\left(5^{\circ} \mathrm{C}\right)$ relative to maximum activity does correlate with environment (Table 2 ). The correlation between environmental temperature and activity follows the pattern observed by Helmke \& Weyland (1991), who measured activities of crude amylase and protease enzymes isolated from psychrophilic and mesophilic marine bacteria. At $10^{\circ} \mathrm{C}$, the amylase activities of their psychrophilic and mesophilic isolates operated at 37 and $7 \%$, respectively, of their maximal activity. Protease activity followed a similar pattern: psychrophilic enzymes at $10^{\circ} \mathrm{C}$ achieved $3 \%$ of maximal activity, while mesophilic proteases operated at $0.2 \%$ of maximal activities. A similar relationship has been found for sulfate reduction rates at 0 and $1.0^{\circ} \mathrm{C}$ in a cold $\left(3\right.$ to $\left.6^{\circ} \mathrm{C}\right)$ Danish fjord and in Antarctic sediments, where sulfate reduction rates were 4 and 10\% (Danish fjord) and 10 and 29\% (Antarctic) of maximal activities, respectively (Isaksen \& Jørgensen 1996). The correlation between lower ambient environmental temperature and higher relative activity at low temperature suggests an adaptation of the biochemical pathways involved in substrate

Table 2. Ratios of activities at $5^{\circ} \mathrm{C}$ to maximum activities measured at Storfjorden, Hornsund, Aarhus Bay, and Weddewarden

\begin{tabular}{|lccc|}
\hline & $\begin{array}{c}\text { Hydrolysis } \\
\text { rate }\end{array}$ & $\begin{array}{c}\mathrm{O}_{2} \\
\text { consumption }\end{array}$ & $\begin{array}{c}\mathrm{SO}_{4}{ }^{2-} \\
\text { reduction }\end{array}$ \\
\hline Storfjorden & 0.52 & 0.38 & 0.15 \\
Hornsund & 0.73 & 0.43 & 0.13 \\
Aarhus Bay & 0.49 & 0.19 & 0.09 \\
Weddewarden & 0.21 & 0.07 \\
\hline
\end{tabular}

hydrolysis, oxygen consumption, and sulfate reduction such that greater efficiency can be achieved at low temperatures.

\section{Implications of potential hydrolysis rate measurements}

The hydrolysis rates measured here are 'potential' rates because the substrate added to the sediment competes with substrate naturally present in the sediment for enzyme active sites. Since the added substrate represents a very large increase (a minimum of 10 -fold) to the total carbohydrate level measured in sediment porewaters, the competition of naturally occurring polysaccharides, even if one were to make the extreme assumption that all porewater carbohydrate consisted of pullulan, is most probably negligible. These potential hydrolysis rates therefore are most likely zero-order-independent of substrate concentration - and represent the maximum rate at which the enzymes present in the sediment could function if substrate were available in non-limiting quantities. Because bacteria are capable of enzyme induction on time-scales of minutes (Gottschalk 1986), potential hydrolysis rate measurements cannot be used to distinguish between constitutive and inducible enzymes. At each site, the consistency of the temperature-hydrolysis relationship and of the optimum temperature over the entire time interval of each experiment (each TGB typically sampled at 3 to 6 time points; see 'Methods'), however, suggests that substrate hydrolysis was not affected by incubation-time related factors such as the growth of a new bacterial population. The potential hydrolysis rates measured here should therefore reflect the biochemical potential of the microbial population naturally present in the sediments.

A further important point is that we are extrapolating from the activity of one specific class of enzyme-pullulanase enzymes - to activities of other polysaccharide-hydrolyzing enzymes, and to macromoleculehydrolyzing enzymes in general. The specificities and activities of macromolecule-hydrolyzing enzymes are an extremely poorly understood area of the marine carbon cycle, and further investigations of the hydrolysis of other polysaccharides and other types of macromolecules are urgently needed. The apparently widespread occurrence of pullulanase activity in marine systems may be due to its ability to function as a debranching enzyme of starch (White \& Kennedy 1988); starch is a common phytoplankton energy storage product (Lee 1980). In addition, experiments comparing hydrolysis rates of pullulan and laminarin (another linear glucose polysaccharide) in intact sediment cores have demonstrated that both polysaccharides are 
hydrolyzed at comparable rates in Arctic and temperate sediments (Amosti in press).

The close correspondence of potential hydrolysis rates measured at in situ temperatures at all 4 sites (range of 3.5 to $4.6 \mathrm{cuts} \cdot \mu \mathrm{mol} \mathrm{glu} \cdot \mathrm{cm}^{-3} \cdot \mathrm{d}^{-1}$ ) suggests that the enzymes expressed in these different environments may possess similar catalytic capabilities. At the molecular level, structural adaptations to low temperatures can include a reduction of the number of surface salt bridges, lower hydrophobicity, and a reduction in weakly polar interactions relative to comparable mesophilic enzymes, as has been found in an $\alpha$-amylase from a psychrophilic Antarctic bacterium (Feller et al. 1994). These structural features ensure that the 'psychrophilic' enzyme has a greater degree of flexibility and correspondingly higher efficiency at low temperatures than the mesophilic enzyme. These same structural adaptations might also be found in the pullulan-hydrolyzing enzymes from Svalbard. Such adaptations could explain the fact that the highest potential hydrolysis rates were measured in the colder environments (Table 1). While the trade-off for greater flexibility is lowered stability at elevated temperature-i.e. a greater tendency for denaturation at elevated temperatures-the temperature range over which the measurements were made in this experiment was clearly not so high as to cause denaturation of the enzymes. The enzymes from Svalbard may have functioned with greater efficiency over the entire temperature range than did the enzymes from more temperate environments; greater efficiency of the enzymes expressed by organisms growing at low temperatures may therefore account for the trend seen in potential hydrolysis rates. Decreases in temperature might in fact have a more significant influence on enzymatic processes occurring in temperate environments, where enzymes may lack the structural adaptations to low temperatures found in enzymes from permanently cold environments.

It should be noted that Reichardt (1988) has speculated that efficiency of enzymatic hydrolysis in cold environments might result from enhanced enzyme production at low temperatures. Because FLA-polysaccharides measure only the net potential hydrolysis rate, not the absolute quantity of enzymes present, these measurements cannot be used to distinguish between high potential hydrolysis rates due to high catalytic efficiency or to large quantities of enzymes. In any case, the similarity of potential hydrolysis rates across a range of environments contrasts with previous suggestions that temperature limitations on enzyme activities restrict rates of carbon cycling in cold environments (Reichardt 1987, Pomeroy et al. 1991). While the rate at which substrates are hydrolyzed in situ is unknown because we have no information about the in situ concentration of polysaccharides in sediments, the data clearly show that the pullulanase enzymes have the potential to function rapidly, given sufficient substrate.

\section{Implications for carbon cycling}

Given rapid extracellular enzymatic hydrolysis, some factor other than potential hydrolysis rate is likely to control rates of terminal remineralization at the 4 sites. At in situ temperatures, rates of oxygen consumption and sulfate reduction at the 4 sites vary by a factor of nearly 100 , whereas potential substrate hydrolysis rates vary by less than a factor of 2 . In addition, the highest potential rates of substrate hydrolysis occur at Svalbard, where the lowest rates of oxygen consumption and sulfate reduction are found (Table 1). These contrasting observations may be due to the comparison of potential hydrolysis rates, which are most probably independent of in situ substrate concentration, with rates of oxygen consumption and sulfate reduction, which are dependent upon the availability of naturally occurring substrate in the sediments. Additionally, the fact that both the highest rates of oxygen consumption and the highest rates of sulfate reduction are -3 times higher at Hornsund than at Storfjorden suggests that both processes may be limited by a common factor not related directly to temperature. While the total bacterial populations at Hornsund and Storfjorden are not significantly different (U. Berninger pers. comm.), the lower rates of terminal remineralization processes at Storfjorden relative to Hornsund (and the lower rates at the Arctic sites relative to the temperate sites) may indicate that a decreased concentration of suitable substrate limits both oxygen consumption and sulfate reduction. As demonstrated by the potential hydrolysis rate measurements, the enzymes present at both Storfjorden and Hornsund have the inherent capability of rapidly hydrolyzing a suitable substrate. Measurements of potential hydrolysis rates, however, provide no information about the availability of substrates suitable for the enzymes. If only limited quantities of suitable substrates (of the correct macromolecular structure etc.) are naturally present in the environment, the enzymes - no matter how numerous or how high their catalytic efficiency-cannot provide sufficient product to fuel high rates of terminal remineralization processes.

A number of studies have also suggested that bacteria may exhibit decreased affinity for substrate with decreasing temperature (Pomeroy et al. 1991, Nedwell \& Rutter 1994). In this case, macromolecule-hydrolyzing enzymes may function equally or more efficiently as enzymes in warmer environments, but the substrate produced by the enzymes would not be effectively taken up and processed by members of the microbial 
food chain. At Hornsund, however, both oxygen consumption and sulfate reduction rates are approximately 3 times as high as at Storfjorden, although the temperature difference between these 2 stations is only $4.3^{\circ} \mathrm{C}\left(2.6\right.$ vs $\left.-1.7^{\circ} \mathrm{C}\right)$. Unless there is a critical point at which modest differences in temperature lead to significant changes in substrate affinity, the 3 -fold differences in rates measured at the 2 stations implies that the difference between these Arctic sites is more likely due to differences in substrate concentration than to reduced affinity of uptake systems.

Sulfate reduction rates were in fact measured at Svalbard with and without the addition of a mixture of substrates (Sagemann et al. in press). Substrate addition generally had little effect on maximum sulfate reduction rates in shallower sediments ( 8 to $14 \mathrm{~cm}$ ). At slightly greater depth $(15$ to $20 \mathrm{~cm})$, substrate addition produced a doubling of reduction rates over the entire temperature range. The short incubation times (4 to $5 \mathrm{~h}$ ), however, may not have been sufficient for the microbial community to react fully to the substrate addition. Previous studies of Antarctic and Aarhus Bay sediments, which have demonstrated an enhancement of sulfate reduction with substrate addition, have utilized incubation times of $24 \mathrm{~h}$ to $1 \mathrm{wk}$ (Isaksen et al. 1994, Isaksen \& Jørgensen 1996).

Other studies also support the hypothesis that carbon turnover in Arctic environments is not necessarily slower than organic carbon turnover in temperate environments, but may be controlled by substrate concentration. Wheeler et al. (1996) and Hodson et al. (1981) found that bacterial activity in Arctic and Antarctic waters, respectively, is comparable to activity measured in temperate coastal waters. Vetter \& Deming (1994) likewise concluded that particulate organic carbon transformations in Arctic slope sediments could occur at rates similar to those of more temperate environments.

The hypothesis that oxygen consumption rates and sulfate reduction rates in the Arctic are constrained by substrate availability, not temperature, is also supported by other work. Meyer-Reil \& Köster (1992) found that addition of 'detrital material' stimulated rates of enzymatic hydrolysis in sediments from the Norwegian-Greenland Sea and concluded that organic matter concentration, not temperature, regulated rates of enzymatic hydrolysis in pelagic sediments. Nedwell et al. (1993) concluded that seasonal variations in sulfate reduction and oxygen uptake in Antarctic sediments were due to changes in organic matter input, not to temperature effects. Thingstad \& Martinussen (1991) likewise found that variations in substrate availability during a phytoplankton bloom, rather than temperature constraints, controlled bacterial activity in the Barents Sea.
Two distinct factors may explain the different levels of activity observed at optimum temperatures for the initial and the terminal steps of organic carbon remineralization. The observation that potential hydrolysis rates at in situ temperatures are comparable across the 4 environments suggests that the enzymes found in Arctic and temperate sediments have similar catalytic efficiencies, or are produced in quantities sufficient to provide comparably high potential rates of hydrolysis. Although potential hydrolysis rates demonstrate that the enzymes have the capability of rapidly hydrolyzing polysaccharides, they provide no information about the availability of substrate in sediments. The 3 -fold differences in oxygen consumption and sulfate reduction rates between Hornsund \& Storfjorden, despite the similarities in potential hydrolysis rates, suggest that terminal remineralization processes in Storfjorden land in Svalbard as compared to the temperate environments) may be constrained by a lower concentration of suitable substrate.

Acknowledgements. We thank D. Canfield (chief scientist) for his efforts to ensure that the Svalbard cruise was well organized and went smoothly. We also appreciate the help of the captain and crew of the RV 'Jan Mayen'. S. Fleischer provided skillful technical assistance. Three anonymous reviewers provided extensive comments about the manuscript. This project was supported by the Max-Planck Society; funding for C.A. - was also provided by the National Science Foundation and the Petroleum Research Fund.

\section{LITERATURE CITED}

Antranikian G (1992) Microbial degradation of starch. In: Winkelman $G$ (ed) Microbial degradation of natural products. Verlag Chemie, New York, p 27-56

Arnosti C (1995) Measurement of depth- and site-related differences in polysaccharide hydrolysis rates in marine sediments. Geochim Cosmochim Acta 59:4247-4257

Arnosti C (1996) A new method for measuring polysaccharide hydrolysis rates in marine environments. Org Geochem 25:105-115

Arnosti C (in press) Rapid potential rates of extracellular enzymatic hydrolysis in Arctic sediments. Limnol Oceanogr

Arnosti C, Repeta DJ (1994) Extracellular enzyme activity in anaerobic bacterial cultures: evidence of pullulanase activity among mesophilic marine bacteria. Appl Environ Microbiol 60:840-846

Arnosti C, Repeta DJ, Blough NV (1994) Rapid bacterial degradation of polysaccharides in anoxic marine systems. Geochim Cosmochim Acta 58:2639-2652

Brown SH, Costantino HR, Kelly RM (1990) Characterization of amylolytic enzyme activities associated with the hyperthermophilic archaebacterium Pyrococcus furiosus. Appl Environ Microbiol 56:1985-1991

Brown SH, Kelly RM (1993) Characterization of amylolytic enzymes, having both $\alpha-1,4$ and $\alpha-1,6$ activity, from the thermophilic archaea Pyrococcus furiosus and Thermococcus Litoralis. Appl Environ Microbiol 59:2614-2621 
Burini JF, Gugi B, Merieau A, Guespin-Michel JF (1994) Lipase and acidic phosphatase from the psychrotrophic bacterium Pseudomonas fluorescens: two enzymes whose synthesis is regulated by the growth temperature. FEMS Microb Lett 122:13-18

Crill PM. Martens CS (1987) Biogeochemical cycling in an organic-rich coastal marine basin. 6. Temporal and spatial variations in sulfate reduction rates. Geochin Cosmochim Acta 51:1175-1186

Delille D. Perret E (1989) Influence of temperature on the growth potential of southern polar marine bacteria. Microb Ecol 18:117-123

Elsgaard L, Isaksen MF, Jorgensen BB, Alayse AM, Jannasch HW (1994) Microbial sulfate reduction in deep-sea sediments at the Guaymas Basin hydrothermal vent area: influence of temperature and substrates. Geochim Cosmochim Acta 58:3335-3343

Feller G, Lonhienne T, Deroanne C, Libioulle C, Van Beeummen J, Gerday C (1992) Purification, characterization, and nucleotide sequence of the thermolabile $\alpha$-amylase from the Antarctic psychrotroph Alteromonas haloplanctis A23. $J$ Biol Chem 267:5217-5221

Feller G, Narinx E, Arpigny JL, Aittaleb M, Baise E, Genicot S, Gerday C (1996) Enzymes from psychrophilic organisms. FEMS Microbiol Rev 18:189-202

Feller G, Payan F, Theys F, Qian M, Haser R, Gerday C (1994) Stability and structural analysis of $\alpha$-amylase from the Antarctic psychrophile Alteromonas haloplanctis A23. Eur $\mathrm{J}$ Biochem 222:441-447

Fossing $H$, Jørgensen BB (1989) Measurement of bacterial sulfate reduction in sediments: evaluation of a single-step chromium reduction method. Biogeochem 8:205-222

Godshalk GL, Wetzel RG (1978) Decomposition in the littoral zone of lakes. In: Good RE, Whigham DF, Simpson RL (eds) Freshwater wetlands: ecological processes and management potential. Academic Press, New York, p 131-143

Gottschalk G (1986) Bacterial metabolism. Springer-Verlag, Berlin

Grasshoff K (1983) Determination of oxygen. In: Grasshoff K, Ehrhardt M, Kremling K (eds) Methods of seawater analysis. Verlag Chemie, Basel, p 419

Hansen JW, Thamdrup B, Fossing H, Jorgensen BB (1994) Redoxbalancen og mineraliseringens temperaturafhaengighed i Aarhus Bugt. Report 36, Ministry of the Environment, Copenhagen

Helmke E, Weyland H (1991) Effect of temperature on extracellular enzymes occurring in permanently cold marine environments. Kiel Meeresforsch Sonderh 8:198--204

Hodson RE, Azam F, Carlucci AF, Fuhrman JA, Karl DM. Holm-Hansen $O$ (1981) Microbial uptake of dissolved organic matter in McMurdo Sound, Antarctica. Mar Biol 61:89-94

Isaksen MF, Bak F, Jorgensen BB (1994) Thermophilic sulfate-reducing bacteria in cold marine sediment. FEMS Microb Ecol 14:1-8

Isaksen MF, Jørgensen BB (1996) Adaptation of psychrophilic and psychrotropic sulfate-reducing bacteria to permanently cold marine environments. Appl Environ Microbiol $62: 408-414$

Jorgensen $B B$ (1978) A comparison of methods for the quantification of bacterial sulfate reduction in coastal marine sediments. Geomicrobiol J 1:11-27

Jørgensen BB (1982) Mineralization of organic matter in the sea bed-the role of sulphate reduction. Nature 296 . $643-645$

Lee RE (1980) Phycology. Cambridge University Press, Cambridge
Li WKW, Dickie PM (1987) Temperature characteristics of photosynthetic and heterotrophic activities: seasonal variations in temperate microbial plankton. Appl Environ Microbiol 53:2282-2295

Mayer LM (1989) Extracellular proteolytic enzyme activity in sediments of an intertidal mudflat. Limnol Oceanogr 34: 973-981

Meyer-Reil LA, Köster M (1992) Microbial life in pelagic sediments: the impact of environmental parameters on enzymatic degradation of organic material. Mar Ecol Prog Ser 81:65-72

Morita (1975) Psychrophilic bacteria. Bacteriol Rev 39:144- 167

Nedwell DB, Rutter M (1994) Influence of temperature on growth rate and competition between two psychrotolerant Antarctic bacteria: low temperature diminishes affinity for substrate uptake. Appl Environ Microbiol 60:1984-1992

Nedwell DB, Walker TR, Ellis-Evans JC, Clarke A (1993) Measurements of seasonal rates and annual budgets of organic carbon fluxes in an Antarctic coastal environment at Signy Island, South Orkney Islands, suggest a broad balance between production and decomposition. Appl Environ Microbiol 59:3989-3995

Norkrans B, Stehn BO (1978) Sediment bacteria in the deep Norwegian Sea. Mar Biol 47:201-209

Parsons TR, Stephens K, Strickland JDH (1961) On the chemical composition of eleven species of marine phytoplankton. J Fish Res Bd Can 18:1001-1016

Pomeroy LR, Wiebe WJ, Deibel D, Thompson RJ, Rowe GT, Pakulski JD (1991) Bacterial responses to temperature and substrate concentration during the Newfoundland spring bloom. Mar Ecol Prog Ser 75:143-159

Rasmussen H, Jorgensen BB (1992) Microelectrode studies of seasonal oxygen uptake in a coastal sediment: role of molecular diffusion. Mar Ecol Prog Ser 81:289-303

Reichardt W (1987) Differential temperature effects on the efficiency of carbon pathways in Antarctic marine benthos. Mar Ecol Prog Ser 40:1127-135

Reichardt W (1988) Impact of the Antarctic benthic fauna on the enrichment of biopolymer degrading psychrophilic bacteria. Microb Ecol 15:311-321

Sagemann J, Jørgensen BB, Greef O (in press) Temperature dependence and rates of sulfate reduction in cold sediments of Svalbard. Geomicrobiol J

Sagemann, J, Skowronek F, Dahmke A, Schulz HD (1996) Pore-water response on seasonal environmental changes in intertidal sediments of the Weser Estuary, Germany. Environ Geol 27:362-369

Tan TL, Rüger HJ (1991) Biomass and nutritional requirements of psychrotrophic bacterial communities in Fram Strait and Western Greenland Sea. Kiel Meeresforsch Sonderh 8:219-224

Thamdrup B, Fleischer $\mathrm{S}$ (in press) Temperature dependence of oxygen respiration, nitrogen mineralization, and nitrification in Arctic sediments. Aquat Microb Ecol

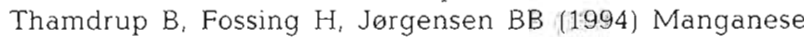
iron, and sulfur cycling in a coastal marine sediment Aarhus Bay, Denmark. Geochim Cosmochim Acta 58 $5115-5129$

Thamdrup B, Hansen JW, Jørgensen BB (in press) Temperature dependence of aerobic respiration in a coastal sediment. FEMS Microb Ecol

Thingstad TF, Martinussen I (1991) Are bacteria active in the cold pelagic ecosystem of the Barents Sea? Polar Res 10 : 255-266

Vetter YA, Deming JW (1994) Extracellular enzyme activity in the Arctic Northeast Water polynya. Mar Ecol Prog Ser 114:23-34 
Weiss MS, Abele U, Weckesser J, Welte W, Schiltz E, Schulz GE (1991) Molecular architecture and electrostatic properties of a bacterial porin. Science $254: 1627-1630$

Westrich JT, Berner RA (1988) The effect of temperature on rates of sulfate reduction in marine sediments. Geomicrobiol J 6:99-117

Editorial responsibility: Jed Fuhrman (Contributing Editor), Los Angeles, California, USA
Wheeler PA, Gosselin M, Sherr E, Thibault D, Kirchman DL, Benner R, Whitledge TE (1996) Active cycling of organic carbon in the central Arctic Ocean. Nature 380:697-699

White CA, Kennedy JF (1988) The carbohydrate-directed enzymes. In: Kennedy JF (ed) Carbohydrate chemistry. Clarendon Press, Oxford, p 343-377

Submitted: April 10, 1997; Accepted: January 10, 1998 Proofs received from author(s): March 31, 1998 